Article

\title{
Chemical-Physical, Sensory Analyses and Consumers' Quality Perception of Local vs. Imported Loquat Fruits: A Sustainable Development Perspective
}

\author{
Riccardo Testa $₫$, Giuseppina Migliore *®D, Giorgio Schifani $₫$, Ilenia Tinebra $₫$ and \\ Vittorio Farina
}

Department of Agricultural, Food and Forestry Sciences, University of Palermo, Viale delle Scienze, Edificio 4, 90128 Palermo, Italy; riccardo.testa@unipa.it (R.T.); giorgio.schifani@unipa.it (G.S.); ilenia.tinebra@unipa.it (I.T.); vittorio.farina@unipa.it (V.F.)

* Correspondence: giuseppina.migliore@unipa.it; Tel.: +39-091-23896618

Received: 6 May 2020; Accepted: 15 June 2020; Published: 18 June 2020

\begin{abstract}
Local products and their distribution through short supply chains play a key role in the sustainable development of many rural areas, as affirmed by the 2030 Food and Agriculture Organization of the United Nations (FAO) Agenda. Moreover, in the last years, more and more consumers have shown a specific interest towards local production, pushed by the need for healthy eating, protecting the environment, and boosting the local economy. However, the cultivation of local fruit varieties or ecotypes has considerably decreased in the last decades because of their low production potential. As a result, many farmers have been forced to replace local orchards with few worldwide grown cultivars, causing a loss of genetic agrobiodiversity. For instance, in Italy, the loquat market is composed of imported cultivars and local grown autochthonous fruits (ecotype). Therefore, the aim of this study is to analyze the chemical-physical and sensory qualities, as well as the determinants of Italian consumer preference towards local ecotype of loquat fruit compared to imported varieties. Results show that local ecotypes result in excellent physico-chemical and sensory attributes, and that place of purchase and taste are the most important factors influencing consumers' preference towards local loquats. Therefore, the cultivation of loquat ecotypes, together with effective marketing strategies, could increase the competitiveness of certain Italian rural areas, where this crop has always played a significant role in the economy.
\end{abstract}

Keywords: ecotypes; Italy; Spain; consumer behavior; short supply chain; organoleptic characteristics

\section{Introduction}

According to the 2030 Food and Agriculture Organization of the United Nations (FAO) Agenda for Sustainable Development, every country by 2030 should allocate public and private financial resources to develop and carry out relevant strategies and programs aimed at ensuring economically, environmentally, and socially sustainable development [1]. In order to reach these objectives by 2030, the Agenda identifies 17 sustainable development goals with 169 associated targets, which entered into force on 1 January 2016, ranging from ending poverty and hunger to responding to climate change and sustaining global natural resources. Ensuring sustainable consumption and production patterns represents one of the main goals since agriculture plays a key role in feeding the world population and ensuring the development of sustainable food production systems. In order to be sustainable, cropping systems, on the one hand, should increase the farmers' income by means of higher quality products [2], and on the other hand, these systems should reduce the negative social and environmental impacts, thanks to the preservation, valorization, and promotion of local production and distribution [3]. Indeed, 
from an environmental point of view, local products and their distribution through short supply chains (SSCs) [4] reduce food-miles and the associated transportation greenhouse gas emissions due to the shortened travel distances and to less use of refrigerated cargo ships, airplanes, or trucks $[5,6]$. In many crops and also in fruit species, the proximity of the markets allows local growers to harvest the fruit close to their maturity stage, resulting in excellent sensorial attributes [7]. Nevertheless, Italian local fruit production is based on nonautochthonous cultivars and local genotype-defined ecotypes (or landraces) [8]. Ecotypes are adapted to the areas in which they grow and, therefore, are fitted to local conditions [9]. Unfortunately, in fruit species, the cultivation of local ecotypes has considerably decreased in the last decades. Due to the necessity to optimize the yield, the cultivation of less productive traditional varieties has been reduced.

Furthermore, a few worldwide grown fruit cultivars have become predominant even though the local ecotypes have specific quality traits [10] that require lower chemical input, significantly reducing their release into the air, water, and soil and minimizing the adverse impacts on human health and the environment [11]. Several studies, in fact, have denoted that the introduction of allochthonous varieties could alter the existent ecosystems and biodiversity or not adapt to it, forcing farmers to increase agricultural inputs to optimize the yields [12]. Nevertheless, landraces, even if they are well adapted to local conditions, are considered obsolete [13]. In fact, demands of large-scale retail distribution increasingly exclude local varieties and ecotypes and replace them with modern cultivars, leading to a dramatic loss of genetic agrobiodiversity. On the other hand, there is a strong congruence between sales in local markets and autochthonous productions. In this regard, short supply chains play an important role in the selling of local production [14].

Furthermore, according to the literature, local production and their distribution through short supply chains allow farmers to reach social and economic sustainability, especially in small-sized farms, and support the economy of rural regions by increasing the social interaction among farmers and other economic actors, especially consumers [15].

From a consumer's perspective, the literature on consumers' choices highlights that the demand for local and typical productions is affected by the need for healthy eating, protecting the environment, and boosting the local economy [16-19] by avoiding the phenomena of rural exodus still present in many rural areas [20]. In many cases, local fruit productions are included in the list of European products that have obtained Protected Geographical Indication (PGI) status and are characterized by excellent qualitative traits such as a persistent aroma and excellent flavor, a developed nutraceutical value that is highly appreciated by consumers [21,22].

However, to the best of our knowledge, no scientific studies have compared local and nonlocal production, and in particular, local fruit production, both from a productive-qualitative point of view, as well as from the consumer's perspective.

The aim of the present study is to analyze the chemical-physical and sensory qualities, as well as the determinants of Italian consumer preference towards local loquat fruits, compared to imported loquat varieties.

Loquat (Eriobotrya japonica Lindl.) is a fruit little explored in the literature. It is an evergreen tree originating from southeastern China. From Japan, loquat was introduced in Italy at the beginning of the last century [23] and spread out into several countries, adapting to subtropical and temperate climates in the same areas where citrus can be grown [24]. Nowadays, loquat is cultivated in many countries of the world, such as China, Japan, India, Pakistan, Cyprus, Egypt, Greece, Israel, Italy, Spain, Tunisia, and Turkey [25], and it has adapted well and is cultivated in the Mediterranean climate [26]. It blooms in fall and early winter, and its white flowers give rise to spherical-oval pomes. In Italy, according to latest available data [27], loquat is cultivated almost totally in the northern coast of Sicily, especially in Palermo Province, where an area of 400 hectares and a harvested production of 4843 tons represent, respectively, $72.8 \%$ and $81.8 \%$ of Italian loquat production. We have focused our attention on Sicily since it represents a biodiversity hotspot for loquat because of its numerous local ecotypes [13]. They were originated from seed propagation, plant visual selection, and then by 
using agamic propagation [28]. Sicilian autochthonous loquat trees are characterized by orange-flesh and white-flesh fruit. White-flesh ecotypes are characterized by a pale-yellow color and belong to the sub-acidic category (called "vanilla") with a high sugar/acid ratio [29] and are very delicate in manipulation and subjected to storage and transport disease [30]. Large differences in terms of external and internal quality were found between yellow-flesh and white-flesh fruit, but both typologies produce a fruit that is appreciated by local consumers and can, therefore, be considered excellent competitors in international markets, standing out for quality and being highly appreciated by consumers [7].

In particular, Farina et al. [13] have conducted several studies on locally grown autochthonous loquat by combining instrumental and sensory analyses of nutraceutical values and differences with the nonautochthonous cultivar. However, these ecotypes are threatened by a few nonautochthonous varieties, mainly Spanish ones, that are increasingly widespread on the Italian market, leading to problems of competitiveness in Italian loquat farms, which are also characterized by obsolete orchards and a lack of commercial organization [31]. Indeed, despite the fact that Sicily has the most suitable ecological conditions for growing loquat and it is particularly suitable for early production, over the last ten years (2009-2018), a reduction both in terms of cultivated areas (-17.4\%) and harvested production $(-21.1 \%)$ has been denoted. This leads to a reduction in the social and economic sustainability of rural areas since many farmers are forced to replace loquat orchards with other crops or abandon their farms, causing a loss of knowledge and biodiversity also associated with exodus phenomena. Therefore, this paper, by providing scientific data on the qualitative characteristics of Italian loquat ecotypes and the consumers' perception of them, has a twofold purpose: (a) to support stakeholders to valorize local production by means of effective marketing strategies; (b) to help entrepreneurs fully satisfy their consumers' needs. This could increase the competitiveness of loquat in Sicily, where this crop has always played a significant role in the economy of territory production.

\section{Materials and Methods}

\subsection{Chemical-Physical and Sensory Analyses}

All examined fruits $(n=60)$ were purchased from two different large commercial distributions at the same time. At the first point of sale, the fruits were imported from Spain, whereas the second one sold autochthonous fruit. However, the variety at the time of purchase was not indicated on the packages. The fruits were transported at the laboratory and immediately analyzed.

Table 1 shows the commercial features of the fruits analyzed. In particular, in all the fruits, fruit weight (FW), pulp weight (PW), skin weight (SW), and seed weight (SeW) were determined by a digital scale (Gibertini, Italia). The transverse diameter (D), and longitudinal diameter (L) was evaluated by digital caliber. In addition, the fruits form index (IF) was calculated using the following equation [32]:

$$
\mathrm{IF}=(\mathrm{D} / \mathrm{L})
$$

Additionally, a commercial classification by category was carried out on all the fruits. These fruits were classified based on the transversal diameter by a commercial cooperative, where GGG $>53 \mathrm{~mm}$, GG: $46-52 \mathrm{~mm}, \mathrm{G}: 32-45 \mathrm{~mm}$, and M: 31-28 mm [33].

For the color evaluation of the skin and pulp, a digital colorimeter was used (Minolta, mod. CR-300; Osaka, Japan) and the CIEL ${ }^{*} a^{*} b^{*}$ scales were used to evaluate the color, where $L^{*}$ (brightness) $0=$ black and $100=$ white; $\mathrm{a}^{*}(-)=$ green and $(+)=$ red; $\mathrm{b}^{*}(-)=$ blue and $(+)=$ yellow. Each fruit was submitted to two measurements on the two opposite sides of the skin and two after being peeled.

The juice was extracted from six different groups of five fruits, three groups for each origin, and was submitted for chemical analysis. The pulp of each fruit was extracted using a centrifugal juicer (Ariete, Italy) to obtain juice in order to evaluate juice content $(\mathrm{J})$ per $100 \mathrm{~g}$. Therefore, the soluble solids content (TSSC) was measured with a digital optical refractometer ( Atago Co, Ltd., Tokyo, Japan). Titratable acidity (TA) was determined according to method 942.15 (AOAC, 2000). The sample was diluted 1:1 by weight of loquat pulp and distilled water using a homogenizer (Fisher Scientific PCR 
125 FTH-115, Milano, Italy) for 1 min at medium speed. Subsequently, $10 \mathrm{~mL}$ of the above solution was titrated with $0.1 \mathrm{~N} \mathrm{NaOH}$ until the solution turned pink. TA results were expressed in $\mathrm{g}$ malic acid/100 $\mathrm{g}$ fresh fruit. We also determined the TSSC/TA ratio.

Table 1. Commercial features of imported (nonautochthonous) and local (autochthonous) loquats analyzed during the experiment. Longitudinal and transversal diameter refers to the single fruit. Values represented as mean $\pm \mathrm{SD}(n=60)$.

\begin{tabular}{|c|c|c|}
\hline \multicolumn{3}{|c|}{ Commercial Features } \\
\hline Origin (Label of Provenience) & Imported/Nonautochthonous & Local/Autochthonous \\
\hline Cultivar/Ecotype & \multicolumn{2}{|c|}{ Not indicated } \\
\hline Weight & $500 \mathrm{~g}$ & $513 \mathrm{~g}$ \\
\hline Longitudinal Diameter & $52.4 \pm 1.50 \mathrm{~mm}$ & $45.4 \pm 1.40 \mathrm{~mm}$ \\
\hline Transversal Diameter & $44.6 \pm 1.10 \mathrm{~mm}$ & $42.4 \pm 1.60 \mathrm{~mm}$ \\
\hline IF (fruits form index) & $0.76-0.94$ & $0.86-1.01$ \\
\hline Commercial class & G & G \\
\hline Storage $\mathrm{T}^{\circ}$ & \multicolumn{2}{|c|}{$20-22{ }^{\circ} \mathrm{C}$} \\
\hline Tracking & Yes & No \\
\hline Packaging & Tray/PE & Bags/PE \\
\hline Peelability & Mean & Easy \\
\hline Price of Loquat & EUR 1.98 & EUR 2.50 \\
\hline
\end{tabular}

The sensorial analysis was carried out by a semitrained panel consisting of ten judges who took into consideration 12 qualitative descriptors (Table 2) evaluated with a 9-point category scale. The sensory analysis was conducted at the postharvest laboratory of the University of Palermo. The sensory evaluation test was performed by five men and five women, 25-40 years old. All panelists were trained and had broad expertise in the sensory evaluation of fruits [7,13]. The judges evaluated the intensity of each descriptor by assigning categorical scores of 1 (absence of sensation), 2 (just recognizable), 3 (very weak), 4 (weak), 5 (slight), 6 (moderate), 7 (intense), 8 (very intense), and 9 (extremely intense). During the evaluation, all panelists completed a short questionnaire covering the quality indicators independently. The order of presentation of the fruits was randomized for each participant, and water was provided for oral rinsing between the different fruit samples. Each panelist received in a random order a sample of 3 anonymous loquat fruits. The data were collected and processed by a spider plot to indicate the overall judgment for each variety.

Table 2. Descriptors used in the sensorial evaluation of loquat fruits.

\begin{tabular}{cc}
\hline Descriptors & \\
\hline Skin color & SC \\
Firmness & FF \\
Pulp color & PC \\
Odor loquat & OL \\
Off-odor & OO \\
Sweetness & SW \\
Acidity & AC \\
Bitter & BT \\
Juiciness & JUI \\
Flavor loquat & FL \\
Browning & BR \\
Aesthetic defects & AD \\
\hline
\end{tabular}




\subsection{Consumers' Quality Perception}

In order to measure the determinant effects of participants' preference for Italian loquat, an online survey was carried out on 301 Italian consumers in summer-autumn 2018. More indepth, participants were recruited through invitations to participate in the online survey by means of the snowball sampling recruitment technique. Although it did not provide a fully representative sample, it allowed researchers to collect a wide variety of information in a short period of time and with moderate costs [34].

Of these 301 consumers, 16 did not complete the survey; therefore, only 285 questionnaires were suitable for the analysis. The questionnaire, administered by means of Google Forms and consisting of 14 items, was structured in two parts. The first part included all variables concerning the socioeconomic characteristics of the interviewees, such as age, gender, education (divided into four categories: primary school, lower secondary school, upper secondary school, university degree or higher), number of household members, and monthly household net income in euros. Moreover, in this section, the frequency of consumption of loquat fruits was also gathered. We did not ask if participants had knowledge about the origin of the fruits since, by Italian law, sellers are obliged to display the origin of the fruit with a tag.

In particular, out of 285 participants in the survey, just over half were female (52.6\% of the respondents), with an average age of 34 years old (ranging from 19 to 69 years; Table 3).

Table 3. Sociodemographic characteristics of respondents.

\begin{tabular}{ccc}
\hline Variables & Items & \% \\
\hline \multirow{2}{*}{ Gender } & Male & 47.4 \\
& Female & 52.6 \\
\hline \multirow{2}{*}{ Age (year) } & $19-29$ & 34.7 \\
& $30-39$ & 31.6 \\
& $40-49$ & 12.7 \\
& $50-59$ & 16.8 \\
& $60-69$ & 4.2 \\
\hline \multirow{2}{*}{ Education } & Lower secondary school & 3.2 \\
& Upper secondary school & 36.7 \\
& University & 32.7 \\
& Master's degree and Ph.D & 27.4 \\
\hline \multirow{2}{*}{ Household monthly income (euro) } & $<1300$ & 17.9 \\
& 1300-2300 & 47.3 \\
& $2301-3300$ & 25.3 \\
& $>3301$ & 9.5 \\
\hline
\end{tabular}

Participants showed a medium-high level of education, as $60.1 \%$ of interviewees had at least a degree, while the majority of them declared a household monthly net income between 1300 and 2300 euros. Regarding the frequency of consumption, $52 \%$ of the participants declared that during the production season, they consumed loquat fruits at least one to several times a week, while the remaining portion declared they consumed it once every two weeks ( $27 \%$ of respondents) or rarely (21\% of respondents).

In the second part of the questionnaire, interviewees were presented with a set of loquat fruit quality characteristics (Table 4) and asked to rate the importance of each quality characteristic using a Likert scale ranging from 1 to 7 (where 1 was not important, and 7 was highly important). This section also collected information on preferences for the place of purchase: short supply chain (SSCs) compared to large-scale retail distribution. 
Table 4. Quality characteristics presented in the questionnaire.

\begin{tabular}{ccccc}
\hline Variable & Mean & Std. Dev. & Min & Max \\
\hline Purchase place (0 = SSCs; 1 = large-scale retail & 0.147 & 0.355 & 0 & 1 \\
distribution) & 5.484 & 1.315 & 1 & 7 \\
Taste & 4.825 & 1.609 & 1 & 7 \\
Healthiness & 6.211 & 1.077 & 1 & 7 \\
Sweetness & 5.842 & 1.169 & 1 & 7 \\
Texiture & 3.632 & 1.794 & 1 & 7 \\
Appearance & 4.200 & 1.487 & 1 & 7 \\
Size & 4.547 & 1.718 & 1 & 7 \\
Cheap price & 2.800 & 1.667 & 1 & 7 \\
Packaging (presence of) & 4.747 & 1.895 & 1 & 7 \\
Organic_certification & & & &
\end{tabular}

SSCs-short supply chains.

Finally, in the questionnaire, we asked consumers to state the preference between local ecotypes and imported varieties. This variable was expressed as a dichotomous variable, where 1 expressed the preference for the Italian ecotypes, while 0 expressed the preference for the imported ones or no preference for the fruit origin.

A logistic econometric model using STATA 11 software (College Station, Texas-U.S.) was implemented to measure the effects of quality characteristics, as well as the sociodemographic factors, on consumer choice [35]. Logistic regression was used to describe data and to explain the relationship between one dependent binary variable (preference for Italian vs. imported loquats) and more nominal, ordinal, or interval independent variables. The basic structure of the logistic regression model can be written as

$$
\operatorname{Ln}\left[\mathrm{P}_{\mathrm{i}} /\left(1-\mathrm{P}_{\mathrm{i}}\right)\right]=\mathrm{b}_{0}+\mathrm{b}_{1} \mathrm{X}_{1}+\mathrm{b}_{2} \mathrm{X}_{2}+\ldots+\mathrm{b}_{\mathrm{n}} \mathrm{X}_{\mathrm{n}}
$$

where $P_{i}$ is the probability that a particular outcome (preference for Italian ecotypes) will occur; $X_{1}$, $\ldots, X_{n}$ are the independent variables from 1 to $n ; b_{1}, \ldots, b_{n}$ are the logistic regression coefficients associated with $\mathrm{X}_{1}, \ldots, \mathrm{X}_{\mathrm{n}} ; \mathrm{b}_{0}$ is the constant. The expression $\left[\mathrm{P}_{\mathrm{i}} /\left(1-\mathrm{P}_{\mathrm{i}}\right)\right]$ is defined as the odds ratio, the natural logarithm of which is termed the logit. In the econometric model, the explanatory variables used to test the relationship with the dependent variable (preference for Italian vs. imported loquats) were those presented in Table 4, plus the sociodemographic characteristics of participants.

\section{Results}

\subsection{Chemical-Physical and Sensory Analyses}

A particular focus has been given to the commercial characteristics of loquat fruits, describing them according to the commercial parameters of the local or imported fruit. Analysis of the results shows that the fruit identity (cultivar/ecotype) of the product is not indicated at the sales point and that all the fruits are stored at room temperature. There is a very small variability in the diameter of the single fruit: this suggests that the fruits, although there is no indication of size in the package, had been sorted by commercial class.

In particular, both imported $(44.6 \mathrm{~mm})$ and local (42.4) fruits belong to the $\mathrm{G}$ class $(32-45 \mathrm{~mm})$, using a commercial classification [33]. Moreover, from the application of a form index (IF) to our samples, we have seen that this value, skin, and pulp color are very similar; hence, we can deduce that both imported and local fruit probably belong to a unique cultivar. Finally, it is important to note that local fruits are very easy to peel.

Figure 1 shows important differences in the pomological traits between imported and local fruit. Although the imported and local fruits do not differ significantly in weight and have the same commercial class, differences can be found in skin weight and seed weight and, consequently, in flesh 
yield. In particular, imported fruit has a higher incidence of skin and seed and, therefore, a lower flesh yield. Pulp/seed ratio, an indicator of the amount of edible parts of the loquat fruit $[7,13]$, was equivalent to 5.00 (local) and 2.72 (imported). This value is important because they are small-sized fruits and the presence of the seeds is not appreciated by consumers who prefer thick-fleshed fruits $[7,36]$.

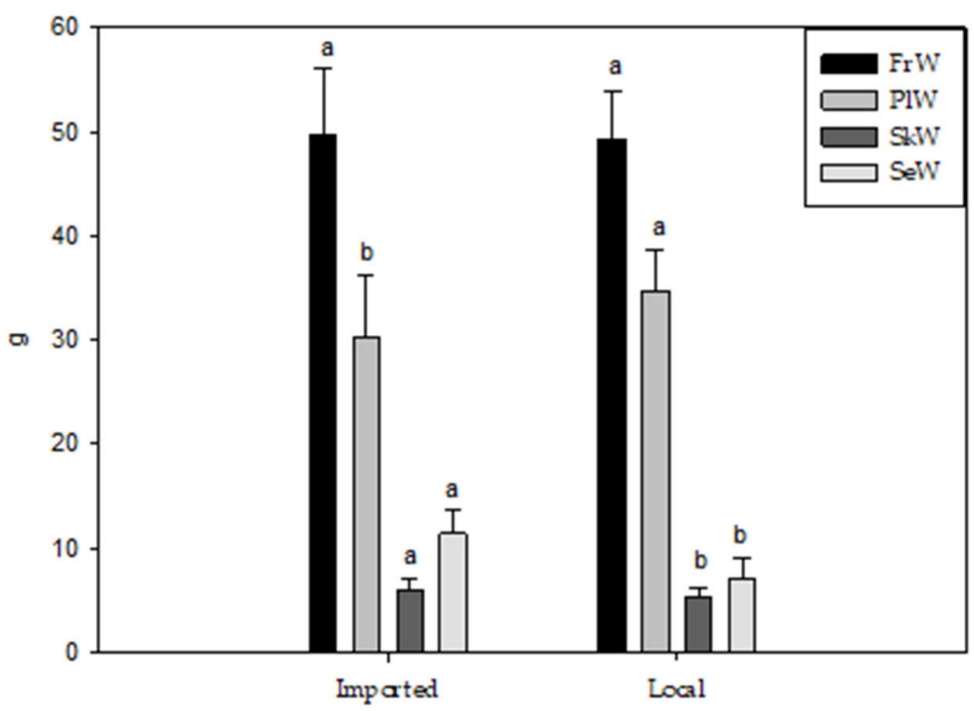

Figure 1. Pomological traits of imported (nonautochthonous) and local (autochthonous) origin loquats. FrW = fruit weight $(\mathrm{g}) ; \mathrm{PlW}=$ pulp weight $(\mathrm{g}) ; \mathrm{SkW}=$ skin weight $(\mathrm{g}) ; \mathrm{SeW}=$ seed weight $(\mathrm{g})$. Values represented as mean $\pm \mathrm{SD}$. For each column, different letters indicate a significant difference at $p \leq 0.05$, as measured by Tukey's multiple range test. Letter "a" denotes the highest value.

Concerning the juice content parameter (J; Table 5), imported fruits have a low juice content with an average value of $36.34 \mathrm{~g} / 100 \mathrm{~g}$; in contrast, local fruits have a higher average value, $45.20 \mathrm{~g} / 100 \mathrm{~g}$. Also, in this case, the consumer prefers a juicy fruit, and this always leads to a better rating during the sensory analysis [37].

Table 5. Chemical-physical traits of imported (nonautochthonous) and local (autochthonous) origin loquats. Juice content (J; g/100 g); soluble solids content (TSSC; ${ }^{\circ}$ Brix); titratable acidity (TA; g malic acid/100 g); TSSC/TA ratio. Values represented as mean \pm SD. For each line, different letters indicate significant differences at $p \leq 0.05$, as measured by Tukey's multiple field test. The letter "a" indicates the highest value.

\begin{tabular}{ccccc}
\hline \multicolumn{4}{c}{ Pomological Traits } \\
\hline Origin (Label of Provenience) & Imported/Nonautochthonous (Spain) & Local/Autochthonous (Italy) \\
\hline Juice content & $36.34 \pm 0.11$ & $\mathrm{~b}$ & $45.20 \pm 0.28$ & $\mathrm{a}$ \\
\hline TSSC & $7.71 \pm 0.89$ & $\mathrm{~b}$ & $12.66 \pm 0.23$ & $\mathrm{a}$ \\
\hline TA & $5.81 \pm 0.03$ & $\mathrm{a}$ & $4.30 \pm 0.76$ & $\mathrm{~b}$ \\
\hline TSSC/TA & $1.33 \pm 0.15$ & $\mathrm{~b}$ & $2.95 \pm 0.50$ & $\mathrm{a}$ \\
\hline
\end{tabular}

Analyzing the fruits from a chemical point of view allows us to evaluate which are the characteristics that most influence the taste. Table 5 shows that the TSSC data significantly differ between local and imported loquat; the local loquat has an average ${ }^{\circ}$ Brix content of 12.66 , which is $60 \%$ higher than the imported loquat. The analysis of the titratable acidity (TA) shows that the local product has a much lower content. Finally, the TSSC/TA ratio was evaluated, which offers a clear idea of the fruits most appreciated by consumers, as fruits with a high ratio are balanced and agreeable to the taste. Generally, values below 1 are judged less positively at tasting than higher values. In some cases, values higher 
than 2 can also be found, with a high taste acceptance $[7,13]$. As can be deduced, local loquat, having a low acid content, have a high TSSC/TA ratio, and reflect consumers' tastes. These first analyses show that local fruits have the ideal characteristics for marketing as they are characterized by uniform size, a high pulp/seed ratio, and a good TSSC/TA ratio.

Following the colorimetric analyses, it was possible to express an aesthetic judgment of the fruit based on the different skin color and pulp color, detected using a colorimeter (Table 6). The skin colorimetric analyses found few significant differences in terms of luminosity and tonality values, as all the samples coming from the local and imported markets had $\mathrm{L}^{*}$ values around 60, and $\mathrm{a}^{*}$ and $b^{*}$ values very similar to each other (Table 6 ). The colorimetric analyses of the pulp, similar to those previously described for the skin, do not show significant differences (Table 6).

Table 6. CIELab ( $\left.L^{*}, a^{*}, b\right)$ and RGB (R, G, B) model of imported (nonautochthonous) and local (autochthonous) origin loquats. Values represented as mean \pm SD. For each column, within the same series, different letters indicate a significant difference at $p \leq 0.05$, as measured by Tukey's multiple range test. Letter "a" denotes the highest value.

\begin{tabular}{cccccc}
\hline \multirow{2}{*}{ Origin } & \multicolumn{2}{c}{ Skin Color } & \multicolumn{2}{c}{ Pulp Color } \\
\cline { 2 - 6 } & & Nonautochthonous & Autochthonous & Nonautochthonous & Autochthonous \\
\hline \multirow{3}{*}{ CIELab } & $\mathrm{L}^{*}$ & $60.40 \pm 0.24 \mathrm{a}$ & $59.6 \pm 0.60 \mathrm{~b}$ & $58.57 \pm 0.90 \mathrm{~b}$ & $61.23 \pm 0.40 \mathrm{a}$ \\
\cline { 2 - 6 } & $\mathrm{a}^{*}$ & $18.14 \pm 0.80 \mathrm{a}$ & $14.07 \pm 0.70 \mathrm{a}$ & $14.83 \pm 0.90 \mathrm{a}$ & $8.11 \pm 0.70 \mathrm{~b}$ \\
\cline { 2 - 6 } & $\mathrm{b}^{*}$ & $47.89 \pm 0.80 \mathrm{a}$ & $45.11 \pm 0.60 \mathrm{a}$ & $44.76 \pm 0.50 \mathrm{a}$ & $43.91 \pm 0.50 \mathrm{a}$ \\
\hline \multirow{3}{*}{ RGB } & $\mathrm{R}$ & $191 \pm 0.40 \mathrm{a}$ & $183 \pm 0.90 \mathrm{a}$ & $179 \pm 0.50 \mathrm{~b}$ & $182 \pm 0.30 \mathrm{a}$ \\
\cline { 2 - 6 } & $\mathrm{G}$ & $133 \pm 0.50 \mathrm{a}$ & $133 \pm 0.20 \mathrm{a}$ & $126 \pm 0.90 \mathrm{~b}$ & $140 \pm 0.40 \mathrm{a}$ \\
\cline { 2 - 6 } & $\mathrm{B}$ & $59 \pm 0.70 \mathrm{a}$ & $62 \pm 0.40 \mathrm{~b}$ & $58 \pm 0.70 \mathrm{a}$ & $67 \pm 0.60 \mathrm{a}$ \\
\hline
\end{tabular}

Regarding sensory analysis, only FF, SW, JUI, and BR descriptors show significant differences between imported and local fruits (Figure 2). The imported fruits showed the highest values of FF and BR, whereas local fruits were sweeter and juicer. Probably these differences were determined by an early harvest due to the handling and transportation needs. By comparing the sensory analysis data with the chemical-physical analyses, it can be seen that some of the panelists' judgments are congruent with the values measured analytically. The fruits of autochthonous origin, in fact, have a good pulp/seed ratio and were also found to have excellent sugar content and low acid. Nonautochthonous fruits, on the other hand, have the lowest soluble sugar content and low juiciness, values that are in line with the results of the panel judgment.

\subsection{Consumers' Quality Perception}

The findings of the logistic econometric model are reported in Table 7.

According to the econometric results, the most important factor that influences participants' preference towards Italian loquat is represented by the place of purchase. In particular, the negative coefficient $(-1.449)$ of this variable means that participants prefer to purchase Italian loquats almost exclusively from local sellers, farmers' markets, and farm shops, rather than large-scale retail distribution.

Among explanatory variables, the findings also show that loquat taste (0.686) and organic certification (0.638) positively affect the consumers' preference towards Italian ecotypes, followed by the cheap price $(0.271)$ recognized in the Italian production, and the perception that the Italian loquats are healthier (0.227) compared to Spanish ones. The presence of packaging, instead, negatively affects the preference towards Italian loquats $(-0.247)$, as respondents associate this item to imported fruits. Relative to some qualitative fruit characteristics, findings show that sweetness, texture, appearance, and size are not statistically significant. This could be due to the high mean values that the respondents 
gave to these variables regardless of their country of origin. As regards the sociodemographic variables, results show that the preference towards Italian loquats is positively affected by "age" (0.074), denoting that older participants prefer local ecotypes. On the contrary, the negative sign of "income" $(-0.440)$ highlights that the preference decreases as income increases. Among the other sociodemographic variables, only "education" and "gender" are not statistically significant. In particular, the nonstatistical significance of education could be due to the high level of education of the participants.

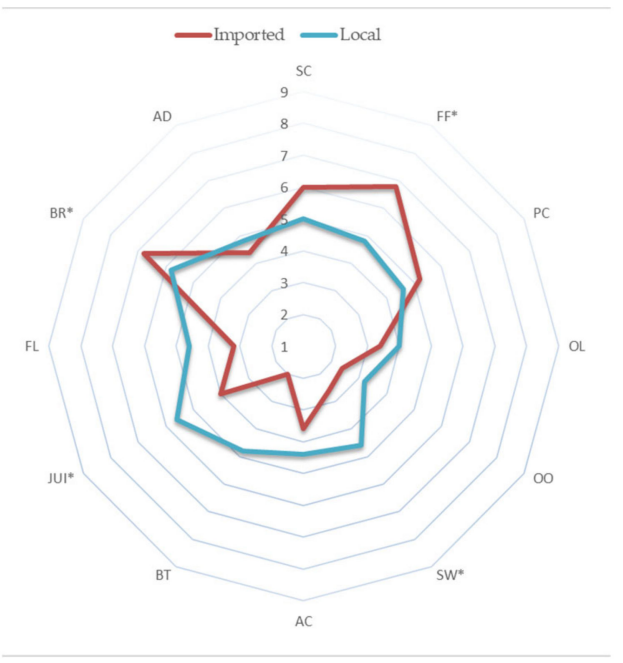

Figure 2. Sensory profile of imported (nonautochthonous) and local (autochthonous) origin loquats, as evaluated by a semitrained panel. Skin color (SC); firmness (FF); pulp color (PC); odor loquat (OL); off-odor (OO); sweetness (SW); acidity (AC); bitter (BT); juiciness (JUI); flavor loquat (FL); browning (BR); aesthetic defects (AD). For each descriptor, the values marked with * indicate significant differences between imported and local fruits.

Table 7. Results of the econometric model.

\begin{tabular}{|c|c|c|c|c|c|c|}
\hline \multicolumn{4}{|l|}{ Logistic Regression } & \multicolumn{3}{|c|}{ Number of Observation $=285$} \\
\hline \multicolumn{2}{|c|}{ Log Likelihood $=-111.333$} & \multirow[b]{2}{*}{ Std. Err. } & \multirow[b]{2}{*}{$\mathrm{z}$} & \multicolumn{3}{|c|}{$\begin{array}{c}\text { LR Chi2 }(11)=107.89^{*} \\
\text { Prob }>\text { Chi2 }=0.0000^{\wedge} \\
\text { Pseudo R2 }=0.3264^{\circ}\end{array}$} \\
\hline $\begin{array}{l}\text { Local vs. Imported } \\
\text { Loquats }\end{array}$ & Coef. & & & $P>|\mathrm{z}|$ & 95\% Conf. & Interval \\
\hline Purchase place & -1.449 & 0.579 & -2.50 & 0.012 & -2.584 & -0.314 \\
\hline Taste & 0.686 & 0.194 & 3.54 & 0.000 & 0.307 & 1.066 \\
\hline Healthiness & 0.227 & 0.116 & 1.95 & 0.051 & -0.001 & 0.455 \\
\hline Sweetness & -0.367 & 0.265 & -1.39 & 0.165 & -0.886 & 0.152 \\
\hline Texture & 0.075 & 0.172 & 0.43 & 0.664 & -0.263 & 0.412 \\
\hline Appearance & -0.001 & 0.128 & 0.00 & 0.996 & -0.251 & 0.250 \\
\hline Size & -0.173 & 0.169 & -1.02 & 0.306 & -0.504 & 0.158 \\
\hline Cheap price & 0.271 & 0.124 & 2.18 & 0.029 & 0.028 & 0.514 \\
\hline Packaging (presence of) & -0.247 & 0.123 & -2.00 & 0.045 & -0.489 & -0.005 \\
\hline Organic certification & 0.638 & 0.123 & 5.16 & 0.000 & 0.396 & 0.879 \\
\hline Age & 0.074 & 0.019 & 3.81 & 0.000 & 0.036 & 0.111 \\
\hline Gender & -0.272 & 0.385 & -0.70 & 0.481 & -1.027 & 0.484 \\
\hline Education & 0.114 & 0.260 & 0.44 & 0.662 & -0.395 & 0.622 \\
\hline Income & -0.440 & 0.120 & -3.66 & 0.000 & -0.676 & -0.204 \\
\hline _cons & -3.672 & 2.074 & -1.77 & 0.077 & -7.736 & 0.393 \\
\hline
\end{tabular}

* LR Chi2 is Likelihood Ratio (LR) Chi-Square. ^ Prob > Chi2 is the probability of obtaining the chi-square statistic given that the null hypothesis is true; ${ }^{\circ}$ Pseudo R2 is a measure of how well variables of the model explain consumer' behavior. 


\section{Discussion}

\subsection{Chemical-Physical and Sensory Analyses}

Due to environmental requirements, most of the loquat production is carried out in the eastern part of Spain, and in particular in Alicante, Andalusia, and Valencia [38]. In Italy, the cultivation is mainly located in Sicily and is destined for the local and national market [13]. In this work, autochthonous and non-autochthonous products have been analyzed.

The first conclusion from the analyses conducted is that the loquat fruits, autochthonous and nonautochthonous, are packaged with uniform size and color and stored at room temperature. From the data in the literature, we know that after harvest, loquat fruit are susceptible to decay, mechanical damage, moisture and nutritional losses [39]. As reported by [40], who stored fully ripe and firm fruit at high $\left(23-25^{\circ} \mathrm{C}\right)$ and low $\left(7-10^{\circ} \mathrm{C}\right)$ temperatures, $65 \%$ spoilage of the fully ripe fruit at the high temperature and $30 \%$ spoilage at the low temperature after 11 days of storage was observed. Moreover, according to the data obtained from Ding et al. [39], the total phenol content in fruit preserved at $20^{\circ} \mathrm{C}$ decreases significantly, and at high temperatures, the phenomenon of senescent breakdown appears more pronounced.

Considering that nonautochthonous loquats are harvested in early spring (March) and then stored for 20-25 days at temperatures of $20-25^{\circ} \mathrm{C}$ [41], they are more sensitive to the damage described before. These considerations are reinforced by physico-chemical analyses.

In fact, a premature harvest results in fruits more sensitive to manipulation, with gradual loss of acidity during storage that affects the final quality of the fruit [42]. In Italy, considering the proximity to markets, loquat fruits are harvested in April when they are already in the second stage of ripeness [43]. This, as shown in Table 4, translates into fruits with a TSSC higher than $60 \%$ compared to imported fruits, with a better TSSC/TA ratio, and, therefore, better appreciated by the consumer.

This is also evidenced by the pulp/seed ratio, a very important parameter for loquats. The flesh to seed ratio is an important feature that indicates the edible part of the fruit, and a high ratio indicates high quality for consumer appreciation [10]. Loquat fruits, in fact, according to Pareek et al. [43], ripen following two phases: In the first phase, there is an increase in the size of the seed; in the second phase, the pulp increases and therefore the sugar content, such as glucose and fructose, aroma, and flavor. An early harvest, like that of nonautochthonous fruits, does not allow the complete development of the pulp in the fruit. From the analyses carried out, in fact, the pulp/seed ratio is higher in Italian fruits, equivalent to 5 .

Moreover, it is important to say that in loquat fruit, the degree of ripeness is closely linked to the expression of the biosynthetic genes of carotenoids [44]; an early harvest, therefore, results in a lower nutraceutical content.

From the sensory analysis, we note that the autochthonous fruit has been more appreciated for its juiciness, sweetness, odor, and loquat flavor (Figure 2). Nonautochthonous fruits, on the other hand, were much appreciated for their firmness, a higher parameter in these than autochthonous fruits. This can be attributed to what was reported by Cai et al. [45], according to which the firmness is accentuated when stored at temperatures of $8-20^{\circ} \mathrm{C}$, but that this increase was positively correlated with an increase in lignin content and caused by the enhanced activities of related enzymes such as phenylalanine ammonia lyase (PAL), cinnamyl alcohol dehydrogenase (CAD), and peroxidase (POD).

Finally, during this study, what we noted is that loquat variety is not indicated in the packages, so although we can find white or yellow pulp loquat on the market, it is difficult to recognize the variety and there is a loss of commercial transparency.

\subsection{Consumers' Quality Perception}

In scientific literature, the purchase place represents an important factor in consumer preferences for local food products [46]. In particular, the survey highlights how respondents prefer to buy Italian loquats from local traders, or directly from farm shops and/or farmers' markets, by associating the sales modality to the fruit origin. This is particularly widespread in the local food sector, where 
the consumers prefer to purchase the products at local traders or alternative food networks (AFNs) compared to large-scale retail distribution [47]. An increasing number of consumers, in fact, are looking for locally produced food, attributing to it greater transparency and information on food origin than traditional sales channels [48]. This is due essentially to globalization, the concentration of agri-food processes, and the numerous food scandals [49], but also to the fact that consumers consider these sales modalities to have a reduced environmental impact, inasmuch as they ensure a shorter distance of transportation of food [50,51]. Moreover, consumers prefer to buy local products in a different place than supermarkets, as they perceive these sales channels to be more socially sustainable because they allow the recirculation of capital resources among several economic actors of a region by supporting the local community $[17,18]$. The last aspect that consumers take into consideration while purchasing local food at AFNs or local traders is that they perceive the products to be healthier and safer compared to the other sales modalities [52,53].

This is clearly highlighted by our research, where the two variables related to the quality of the product, such as taste and healthiness, are important for their preference towards local food, as denoted by numerous previous research [54-56].

Local loquats, in fact, are normally ripened at the optimal maturity stage compared to nonlocal ones, reaching a high physical, chemical, and sensorial quality of fruits and satisfying the consumers' preferences. In this regard, a study conducted by Tan [57] reports that flavor (defined as taste plus odor) represents the main component of eating quality in the majority of fruits and vegetables.

As reported in our analysis, as well as in several studies [58,59], organic certification represents an important factor that affects consumer preference towards local food. However, nowadays, consumers are pushed to buy local products regardless of whether they are organic $[53,60]$, as they blend the concept of local food with other alternative food concepts, such as organic products [61]. In this regard, this is consistent with a recent study by Jensen et al. [62] that denoted that Danish consumers perceive benefits deriving from local products as rather similar to those of organic ones, attributing them to be tastier, safer, and more environmentally friendly than nonlocal ones. This is in line with Migliore et al. [2], who affirmed that the possibility of combining the attributes of "local" and "organic" increases the chances of success and, consequently, the competitiveness of producers.

Unlike some studies that have revealed that the lack of clear identification of local food by means of labels hinders consumers from buying local products [63], and that it also wastes more time in food choice [64], our interviewees affirmed that the presence of packaging reduces their preference towards Italian loquats. This is consistent with Gumirakiza et al. [65], who show that ready-to-eat foods or packaged foods are not strong motivators to buy local food (as consumers perceive unpackaged products as fresher, healthier and more socially sustainable).

Our analysis shows that a lower price positively affects the preference towards Italian loquats, despite several studies denoting that consumers are willing to pay a premium price for local food products compared to other ones $[66,67]$. However, our findings are in line with other previous studies [68,69], whose results denoted that consumers perceive local food as cheaper than products sold in traditional supermarkets or organic ones. Therefore, unlike other previous studies that have denoted that mainly wealthier people purchase local food [65,70], our survey highlights that the local loquats are especially preferred by low-income level buyers, as shown by a research conducted by Racine et al. [71] among North Carolina families.

Among other sociodemographic variables, the survey reveals that age positively affects the preference towards local products, as older people are tied to their traditions and home regions [72] and are more health-conscious compared to younger consumers [73]. Finally, unlike what has been reported by some previous studies, in which consumers with a high level of education and women are more likely to purchase local food [74,75], our results show that both education and gender do not affect the preference of respondents. 


\section{Conclusions}

This study aimed to explore the chemical-physical and sensory qualities, as well as the determinants of Italian consumer preference towards local loquat fruits compared to imported varieties. The findings of the study highlight how local loquat ecotypes express high-quality traits that are particularly popular with consumers, who perceive them to be healthier and tastier than imported varieties. Moreover, consumers perceive short supply chains (such as local sellers, farmers' markets, and farm shops) as an important determinant in purchasing local productions because the direct interaction with farmers is a quality guarantee of social sustainability.

The perceived high quality of local loquats by consumer interviews is corroborated by chemical-physical and sensory analyses. In particular, local ecotypes show the best pulp/seed ratio, juice content, total soluble solid content/titratable acidity ratio, and are more appreciated by the panelists.

Therefore, encouraging the reintroduction of local ecotypes in Italian rural areas could have important implications for sustainable development as local loquat ecotypes ensure both genetic agrobiodiversity in rural areas and help to sustain small and medium farms that currently experience higher use of synthetic chemicals to grow imported loquat varieties.

In this regard, knowing the qualitative and sensory characteristics of local ecotypes and trying to understand how they are perceived and preferred by consumers, compared to imported varieties, allow stakeholders to implement specific and effective marketing strategies aimed at supporting the sustainable socioeconomic development of rural areas. Nevertheless, a deep restructuring of the Italian loquat supply chain is needed in order to create new commercial forms of cooperation among farmers and to introduce process innovations in farming operations.

However, despite the importance of our results, the present study shows some limitations. The most important limitation deals with the analysis of consumer preferences. Although this analysis gives important indications on Italian consumer preferences, it is based on a nonrepresentative sample; thus, the generalizability of the results is limited. Further analyses have to take into account a representative statistical sample in order to overcome this limitation, giving a clear picture of the state of the art of Italian preference towards local loquat ecotypes.

Author Contributions: This study is a result of the full collaboration of all the authors. However, conceptualization, R.T.; methodology G.M. and V.F.; validation, R.T., V.F., and I.T.; formal analysis, G.M. and G.S.; investigation, R.T., V.F., and I.T.; resources, R.T. and I.T.; data curation, G.M., V.F., and I.T.; writing-original draft preparation, R.T. and I.T.; writing - review and editing, R.T., V.F., and G.M.; visualization, I.T. and R.T.; supervision, V.F. and G.S. All authors have read and agree to the published version of the manuscript.

Funding: This research received no external funding.

Conflicts of Interest: The authors declare no conflict of interest.

\section{References}

1. Food and Agriculture Organization of the United Nations (FAO). Transforming Our World: The 2030 Agenda for Sustainable Development. Available online: http://www.fao.org/ (accessed on 2 February 2020).

2. Migliore, G.; Di Gesaro, M.; Borsellino, V.; Asciuto, A.; Schimmenti, E. Understanding Consumer Demand for Sustainable Beef Production in Rural Communities. Qual. Access Success 2015, 16(147), 75-79.

3. Testa, R.; Galati, A.; Schifani, G.; Di Trapani, A.M.; Migliore, G. Culinary Tourism Experiences in Agri-Tourism Destinations and Sustainable Consumption-Understanding Italian Tourists' Motivations. Sustainability 2019, 11, 4588. [CrossRef]

4. Testa, R.; Galati, A.; Schifani, G.; Crescimanno, M.; Di Trapani, A.M.; Migliore, G. Are alternative food networks winning strategies to increase organic SMEs profitability? Evidence from a case study. Int. J. Glob. Small Bus. 2020, 11, 65-82. [CrossRef]

5. Lee, G.E.; Miller, S.R.; Loveridge, S. Modelling local food policy and greenhouse gas emission due to transportation. J. Reg. Anal. Policy 2017, 47, 75-87.

6. Coley, D.; Howard, M.; Winter, M. Local food, food miles and carbon emissions: A comparison of farm shop and mass distribution approaches. Food Policy 2009, 34, 150-155. [CrossRef] 
7. Gentile, C.; Reig, C.; Corona, O.; Todaro, A.; Mazzaglia, A.; Perrone, A.; Farina, V. Pomological traits, sensory profile and nutraceutical properties of nine cultivars of loquat (Eriobotrya japonica Lindl.) fruits grown in Mediterranean area. Plant Foods Hum. Nutr. 2016, 71, 33. [CrossRef]

8. Fideghelli, C.; Engel, P. Biodiversity and local genetic resources: From knowledge to exploitation. I Int. Symp. Hortic. Eur. 2008, 817, 295-310. [CrossRef]

9. Villa, T.C.C.; Maxted, N.; Scholten, M.; Ford-Lloyd, B. Defining and identifying crop landraces. Plant Genet. Resour. 2005, 3, 373-384. [CrossRef]

10. Barone, F.; Farina, V.; Lo Bianco, R. Growth, yield and fruit quality of 'Peluche' loquat under windbreak nets. Acta Hortic. 2011, 887, 155-160. [CrossRef]

11. Bartolini, S.; Viti, R.; Ducci, E. Local fruit varieties for sustainable cultivations: Pomological, nutraceutical and sensory characterization. Agrochimica 2015, 59, 281-294.

12. Hawes, C.; Alexander, C.J.; Begg, G.S.; Iannetta, P.P.M.; Karley, A.J.; Squire, G.R.; Young, M. Plant Responses to an Integrated Cropping System Designed to Maintain Yield Whilst Enhancing Soil Properties and Biodiversity. Agronomy 2018, 8, 229. [CrossRef]

13. Farina, V.; Gianguzzi, G.; Mazzaglia, A. Fruit quality evaluation of affirmed and local loquat (Eriobotrya japonica Lindl) cultivars using instrumental and sensory analyses. Fruits 2016, 71, 105-113. [CrossRef]

14. Migliore, G.; Forno, F.; Guccione, G.; Schifani, G. Food Community Networks as sustainable self-organized collective action: A case study of a solidarity purchasing group. New Medit 2014, 13, 54-62.

15. Schifani, G.; Romeo, P.; Guccione, G.D.; Schimmenti, E.; Columba, P.; Migliore, G. Conventions of quality in consumer preference toward local honey in southern Italy. Qual. Access Success 2016, 17, 92-97.

16. Feldmann, C.; Hamm, U. Consumers' perceptions and preferences for local food: A review. Food Qual. Prefer. 2015, 40, 152-164. [CrossRef]

17. Dodds, R.; Holmes, M.; Arunsopha, V.; Chin, N.; Le, T.; Maung, S.; Shum, M. Consumer choice and farmers' markets. J. Agric. Environ. Ethics 2014, 27, 397-416. [CrossRef]

18. Van Passel, S. Food miles to assess sustainability: A revision. Sustain. Dev. 2013, 21, 1-17. [CrossRef]

19. Bean, M.; Shar, J.S. Profiling alternative food system supporters: The personal and social basis of local and organic food support. Renew. Agric. Food Syst. 2011, 26, 243-254. [CrossRef]

20. Testa, R.; Tudisca, S.; Schifani, G.; Di Trapani, A.M.; Migliore, G. Tropical Fruits as an Opportunity for Sustainable Development in Rural Areas: The Case of Mango in Small-Sized Sicilian Farms. Sustainability 2018, 10, 1436. [CrossRef]

21. Sortino, G.; Farina, V.; Liguori, G.; Inglese, P. Fruit ripening evolution in 'Settembrina Di Leonforte' and 'Gialla tardiva di leonforte' peach (Prunus persica L., Batsch] ecotypes. VIII Int. Peach Symp. 2013, 1084, 791-798. [CrossRef]

22. Tenore, G.C.; Caruso, D.; Buonomo, G.; D’Urso, E.; D’Avino, M.; Campiglia, P.; Novellino, E. Annurca (Malus pumila Miller cv. Annurca) apple as a functional food for the contribution to a healthy balance of plasma cholesterol levels: Results of a randomized clinical trial. J. Sci. Food Agric. 2017, 97, 2107-2115. [CrossRef] [PubMed]

23. Monastra, F.; Insero, O.; Tamponi, G. The present situation of some underutilized fruit crops in Italy. Proc. First Int. Loquat Symp. Options Mediterr. 1994, 13, 39-46.

24. Llácer, G.; Badenes, M.L.; Calvo, J.M. Plant material of loquat in Mediterranean countries. Proc. First Int. Loquat Symp. Options Mediterr. 2003, 58, 45-52.

25. Badenes, M.L.; Janick, J.; Lin, S.; Zhang, Z.; Wang, W.; Liang, G.L. Breeding loquat. In Plant Breeding Reviews; Janick, J., Ed.; Wiley-Blackwell: Hoboken, NJ, USA, 2013; Volume 37, pp. 259-296.

26. Reig, C.; Farina, V.; Mesejo, C.; Martínez-Fuentes, A.; Barone, F.; Agustí, M. Fruit regulates bud sprouting and vegetative growth in field-grown loquat trees (Eriobotrya japonica lindl.): Nutritional and hormonal changes. J. Plant Growth Regul. 2014, 33, 222-232. [CrossRef]

27. Istituto Nazionale di Statistica (ISTAT). Agriculture Statistics. Available online: https://www.istat.it/it/ (accessed on 10 February 2020).

28. Baratta, B.; Campisi, G.; Raimondo, A. Miglioramento genetico del nespolo del Giappone (Eriobotrya japonica Lindl.) cv "Marchetto". Frutticoltura 1995, 1, 27-32.

29. Calabrese, F. Nespolicoltura italiana e spagnola a confronto. Ortoflorofruttic. Ital. 1995, 1, $21-25$. 
30. Adiletta, G.; Pasquariello, M.S.; Zampella, L.; Mastrobuoni, F.; Scortichini, M.; Petriccione, M. Chitosan Coating: A Postharvest Treatment to Delay Oxidative Stress in Loquat Fruits during Cold Storage. Agronomy 2018, 8, 54. [CrossRef]

31. Tudisca, S.; Di Trapani, A.M.; Sgroi, F.; Squatrito, R.; Testa, R. Profitability of small loquat farms in Sicily. Acta Hortic. 2015, 1092, 37-40. [CrossRef]

32. Martínez, J.J.; Hernández, F.; Abdelmajid, H.; Legua, P.; Martínez, R.; El Amine, A.; Melgarejo, P. Physico-chemical characterization of six pomegranate cultivars from Morocco: Processing and fresh market aptitudes. Sci. Hortic. 2012, 140, 100-106. [CrossRef]

33. Stellfeldt, A.; Martín, J.H.; González, J.C.; Del Águila, E.E. Dinámica de Crecimiento del Fruto en Níspero Japonés 'Algerie' Bajo Tratamiento de Riego Deficitario Precosecha. Available online: http://www.sech.info/ACTAS/Acta \%20n\%C2\%BA\%2054.\%20VI\%20Congreso \%20Ib\%C3\%A9rico \%20de\% 20Ciencias $\% 20$ Hort $\%$ C3\%ADcolas. $\% 20$ XII\%20Congreso $\% 20$ Nacional $\% 20$ de $\% 20$ Ciencias $\% 20$ Hort $\%$ C3\%ADcolas/Comunicaciones/Din \%C3\%A1mica \%20de\%20crecimiento\%20del\%20fruto\%20en \%20n \% C3\%ADspero\%20japon\%C3\%A9s\%20\%E2\%80\%98Algerie \%E2\%80\%99\%20bajo\%20tratamiento\%20de $\%$ 20riego\%20deficitario\%20precosecha.pdf (accessed on 18 March 2020).

34. McCullough, D. Web-based market research: The dawning of a new age. Direct Mark. 1998, 61, 36-39.

35. Cameron, A.C.; Trivedi, P.K. Microeconometrics: Methods and Applications; Cambridge University Press: New York, NY, USA, 2005.

36. Mowat, A.; Collins, R. Consumer behaviour and fruit quality: Supply chain management in an emerging industry. Supply Chain Manag. 2000. [CrossRef]

37. Cañete, M.L.; Pinillos, V.; Cuevas, J.; Hueso, J.J. Sensory evaluation of the main loquat cultivars in Spain. II Int. Symp. Loquat 2006, 750, 159-164. [CrossRef]

38. Caballero, P.; Fernández, M.A. Loquat, production and market. Proc. First Int. Loquat Symp. Options Mediterr. 2003, 58, 11-20.

39. Ding, C.K.; Chachin, K.; Hamauzu, Y.; Ueda, Y.; Imahori, Y. Effects of storage temperatures on physiology and quality of loquat fruit. Postharvest Biol. Technol. 1998, 14, 309-315. [CrossRef]

40. Ogata, Y. Physiological study on the fruit of loquat during storage. Tech. Bull. Kagawa Agric. Coll. 1950, 1, 42-55.

41. Paull, R.E. Chilling injury of crops of tropical and subtropical origin. In Chilling Injury of Horticultural Crops; Wang, C.Y., Ed.; CRC Press: Boca Ration, FL, USA, 1990; pp. 17-36.

42. Lin, S.; Sharpe, R.H.; Janick, J. Loquat: Botany and horticulture. Hortic. Rev. 1999, 23, 233-276.

43. Pareek, S.; Benkeblia, N.; Janick, J.; Cao, S.; Yahia, E.M. Postharvest physiology and technology of loquat (Eriobotrya japonica Lindl.) fruit. J. Sci. Food Agric. 2014, 94, 1495-1504. [CrossRef]

44. Zhou, C.H.; Xu, C.J.; Sun, C.D.; Li, X.; Chen, K.S. Carotenoids in white-and red-fleshed loquat fruits. J. Agric. Food Chem. 2007, 55, 7822-7830. [CrossRef]

45. Cai, C.; Xu, C.J.; Li, X.; Ferguson, I.; Chen, K.S. Accumulation of lignin in relation to change in activities of lignification enzymes in loquat fruit flesh after harvest. Postharvest Biol. Technol. 2006, 40, 163-169. [CrossRef]

46. Kadanali, E.; Demir, N. Factors affecting consumers' preferences for purchase place of local food products. J. Anim. Plant Sci. 2018, 28, 1523-1531.

47. Vecchio, R.; European and United States. Farmers' Markets: Similarities, Differences and Potential Developments. In Proceedings of the Presentation at the 113th EAAE Seminar, Chania, Greece, 3-6 September 2009; Available online: http://ageconsearch.umn.edu/bitstream/58131/2/Vecchio.pdf (accessed on 23 March 2020).

48. Holloway, L.; Kneafsey, M.; Venn, L.; Cox, R.; Dowler, E.; Tuomainen, H. Possible food economies: A methodological framework for exploring food production-consumption relationships. Sociol. Rural. 2007, 47, 1-19. [CrossRef]

49. Jones, P.; Comfort, D.; Hillier, D. A case study of local food and its routes to market in the UK. Br. Food J. 2004, 106, 328-335.

50. De Magistris, T.; Gracia, A. The decision to buy organic food products in Southern Italy. Br. Food J. 2008, 110, 929-947. [CrossRef]

51. Lanfranchi, M.; Giannetto, C.; De Pascale, A. Nature based tourism: Natural balance, impacts and management. Qual. Access Success 2014, 15, 224-229. 
52. Kokthi, E.; González Limón, M.; Vázquez Bermúdez, I. Origin or Food Safety attributes? Analyzing consumer preferences using Likert Scale. Empirical evidence from Albania. New Medit 2015, 14, 50-57.

53. Naspetti, S.; Bodini, A. Consumer perception of local and organic products: Substitution or complementary goods? Int. J. Interdiscip. Soc. Sci. 2008, 3, 111-121. [CrossRef]

54. Campbell, B.L.; Mhlanga, S.; Lesschaeve, I. Perception versus reality: Canadian consumer views of local and organic. Can. J. Agric. Econ. 2013, 61, 531-558. [CrossRef]

55. Adams, D.C.; Adams, A.E. De-placing local at the farmers' market: Consumer conceptions of local foods. J. Rural Soc. Sci. 2011, 26, 74-100.

56. Bingen, J.; Sage, J.; Sirieix, L. Consumer coping strategies: A study of consumers committed to eating local. Int. J. Consum. Stud. 2011, 35, 410-419. [CrossRef]

57. Tan, S.C. Determinants of eating quality in fruits and vegetables. Proc. Nutr. Soc. Aust. 2000, 24, 183-190.

58. Wägeli, S.; Hamm, U. Consumers' perception and expectations of local organic food supply chains. Org. Agric. 2016, 6, 215-224. [CrossRef]

59. Hasselbach, J.L.; Roosen, J. Consumer Heterogeneity in the Willingness to Pay for Local and Organic Food. J. Food Prod. Mark. 2015, 21, 608-625. [CrossRef]

60. Onozaka, Y.; Mc Fadden, T.D. Does local labelling complement or compete with other sustainable labels? A conjoint analysis of direct and joint values for fresh produce claims. Am. J. Agric. Econ. 2011, 93, 693-706. [CrossRef]

61. Berlin, L.; Lockeretz, W.; Bell, R. Purchasing foods produced on organic, small and local farms: A mixed method analysis of New England consumers. Renew. Agric. Food Syst. 2009, 24, 267-275. [CrossRef]

62. Jensen, J.D.; Christensen, T.; Denver, S.; Ditlevsen, K.; Lassen, J.; Teuber, R. Heterogeneity in consumers' perceptions and demand for local (organic) food products. Food Qual. Prefer. 2019, 73, 255-265. [CrossRef]

63. Conner, D.; Colasanti, K.; Ross, R.B.; Smalley, S.B. Locally grown foods and farmers markets: Consumer attitudes and behaviors. Sustainability 2010, 3, 742-756. [CrossRef]

64. Zepeda, L.; Leviten-Reid, C. Consumers' views on local food. J. Food Distrib. Res. 2004, 35, 1-6.

65. Gumirakiza, J.D.; Curtis, K.R.; Bosworth, R. Who attends farmers' markets and why? Understanding consumers and their motivations. Int. Food Agribus. Manag. Rev. 2014, 17, 65-82.

66. Costanigro, M.; Kroll, S.; Thilmany, D.; Bunning, M. Is it love for local/organic or hate for conventional? Asymmetric effects of information and taste on label preferences in an experimental auction. Food Qual. Prefer. 2014, 31, 94-105. [CrossRef]

67. Gracia, A.; Barreiro-Hurlé, J.; López-Galán, B. Are local and organic complement or substitutes labels? A Consumer Preferences Study for Eggs. J. Agric. Econ. 2014, 65, 49-67. [CrossRef]

68. Spielmann, N.; Bernelin, M. Locavores: Where you buy defines who you are. Int. J. Retail. Distrib. Manag. 2015, 43, 617-633. [CrossRef]

69. Sirieix, L.; Kledal, P.R.; Sulitang, T. Organic food consumers' trade-offs between local or imported, conventional or organic products: A qualitative study in Shanghai. Int. J. Consum. Stud. 2011, 35, 670-678. [CrossRef]

70. Carpio, C.E.; Isengildina-Massa, O. Consumer willingness to pay for locally grown products: The case of South Carolina. Agribusiness 2009, 25, 412-426. [CrossRef]

71. Racine, E.F.; Mumford, E.A.; Laditka, S.B. Understanding characteristics of families who buy local produce. J. Nutr. Educ. Behav. 2013, 45, 30-38. [CrossRef]

72. Henseleit, M.; Kubitzki, S.; Teuber, R. Determinants of Consumer Preferences for Regional Food. In Proceedings of the Presentation at the 105th EAAE Seminar "International Marketing and International Trade of Quality Food Products", Bologna, Italy, 8-10 March 2007; Available online: http://ageconsearch. umn.edu/bitstream/7871/1/cp070004.pdf (accessed on 24 March 2020).

73. Memery, J.; Angell, R.; Megicks, P.; Lindgreen, A. Unpicking motives to purchase locally-produced food: Analysis of direct and moderation effects. Eur. J. Mark. 2015, 49, 1207-1233. [CrossRef]

74. Strobel, C.; Stockinger, B.T.; Duenbostl, C.; Pöchtrager, S.; Auberger, V. Urban consumers' attitude towards and perception of local food and local food initiatives. J. Austrian Soc. Agric. Econ. 2014, 24, 141-150.

75. Cholette, S.; Ozluk, O.; Ozsen, L.; Ungson, G.R. Exploring purchasing preferences: Local and ecologically labelled foods. J. Consum. Mark. 2013, 30, 563-572. [CrossRef]

(C) 2020 by the authors. Licensee MDPI, Basel, Switzerland. This article is an open access article distributed under the terms and conditions of the Creative Commons Attribution (CC BY) license (http://creativecommons.org/licenses/by/4.0/). 